
A. Mehdizade
K. O. Lovblad
K. E. Wilhelm
T. Somon
S. G. Wetzel
A. D. Kelekis
H. Yilmaz
G. Abdo
J. B. Martin
J. M. Viera
D. A. Rüfenacht

\section{Radiation dose in vertebroplasty}

Received: 6 October 2003

Accepted: 29 November 2003

Published online: 14 February 2004

(C) Springer-Verlag 2004

Presented at the Annual Meeting of the European Society of Neuroradiology in Istanbul, Turkey, September 2003

A. Mehdizade $\cdot$ K. O. Lovblad $(\bowtie)$

K. E. Wilhelm · T. Somon · S. G. Wetzel

A. D. Kelekis $\cdot$ H. Yilmaz $\cdot$ G. Abdo

J. B. Martin · J. M. Viera

D. A. Rüfenacht

Neuroradiology DRRI,

Geneva University Hospital,

Rue Micheli-du-Crest 24,

1211 Geneva 14, Switzerland

E-mail: karl-olof.lovblad@hcuge.ch

Tel.: + 41-22-3727045

Fax: + 41-22-3727072

\begin{abstract}
We wished to measure the absorbed radiation dose during fluoroscopically controlled vertebroplasty and to assess the possibility of deterministic radiation effects to the operator. The dose was measured in 11 consecutive procedures using thermoluminescent ring dosimeters on the hand of the operator and electronic dosimeters inside and outside of the operator's lead apron. We found doses of $0.022-3.256 \mathrm{mGy}$ outside and $0.01-0.47 \mathrm{mGy}$ inside the lead apron. Doses on the hand were higher, $0.5-8.5 \mathrm{mGy}$. This preliminary study indicates greater exposure to the operator's hands than expected from traditional apron measurements.
\end{abstract}

Keywords Vertebroplasty $\cdot$ Radiation dosimetry

\section{Introduction}

Vertebroplasty is an effective interventional radiological procedure consisting of the percutaneous injection of a tissue cement, usually methyl methacrylate, into weakened vertebral bodies $[1,2,3,4]$. The principal indications are osteolytic metastasis and myeloma, painful or aggressive haemangioma, and osteoporotic vertebral collapse with debilitating pain despite appropriate medical treatment. In most institutions the procedure, especially the injection of the cement, is performed under continuous fluoroscopic control to access filling and avoid leakage, which could result in major complications. The radiation risk to the radiologist is therefore high; the absorbed dose might cause deterministic dosedependent damage. There are reports on radiation exposure to the operator in neurodiagnostic and inter- ventional procedures $[5,6,7,8,9,10,11,12,13,14,15$, $16,17,18,19]$, but to our knowledge none is available concerning vertebroplasty procedures. Our aim was therefore to measure the absorbed radiation dose during fluoroscopically controlled vertebroplasty and to evaluate the possibility of deterministic radiation effects to the operator.

\section{Materials and methods}

Over a period of 3 months, 11 patients, six women, five men, mean age 68 years, underwent fluoroscopically guided vertebroplasty for pain due to metastases. They had been referred from the oncology department and were fully informed about the procedure, which has been approved by our ethics committee. Clinical assessment included immediate and follow up studies of the patient's pain, general condition and neurological status. 
The patients were under general anaesthesia and placed prone on the table of the biplanar fluoroscopy unit (BV 3000, Philips, The Netherlands). Imaging was performed with digital subtraction angiography (DSA) equipment fluoroscopic control of needle placement and cement injection into the vertebral body. The interventions were performed by an experienced neuroradiologist with personal experience of more than 300 vertebroplasties. The needle was positioned aiming towards the vertebral body by using fluoroscopic landmarks. An anteroposterior projection was used until the needle passed through the posterior cortex of the vertebral body; thereafter the lateral projection was used. Using biplane fluoroscopy speeds up the procedure. Then contrast medium was injected through the needle to obtain a phlebogram. Methyl methacrylate, (18 cc powder) and barium ( $2 \mathrm{cc})$ were mixed with $5 \mathrm{ml}$ of liquid polymer, giving a mixture with a polymerization time of up to $8 \mathrm{~min}$. This mixture was injected under lateral fluoroscopic control.

Measurements were made on the operator's hand, using a lithium fluoride thermoluminescent dosimeter ring and on the chest with two electronic dosimeters, one inside and one outside the lead apron.

\section{Results}

Total fluoroscopy times were between 10 and $60 \mathrm{~min}$. Tube dosage was 14.5-170.3 mGy (mean $170.3 \mathrm{mGy}$ ). Measurements on the operator were $0.022-3.256 \mathrm{mGy}$ outside and $0.01-0.47 \mathrm{mGy}$ inside the lead apron, and $0.5-8.5 \mathrm{mGy}$ on the hand.

\section{Discussion}

This preliminary study indicates significant exposure to the hands of the operator during percutaneous vertebroplasty, which may be underestimated by traditional apron measurements. It is important to reduce this exposure of the hands by reducing the time the hands are in the radiation field or using devices which can be manipulated with the hands outside it. During vertebroplasty the operator often needs to manipulate the needle under fluoroscopic control to insure proper placement. This can induce radiation damage to the skin after repeated interventions.

Overall the introduction of digital fluorography has significantly reduced radiation dose to the patient [9]. It is important to be aware that high doses per image in digital fluorography does not necessarily improve image quality [10]. Increased filtration can further reduce radiation dose, as has been demonstrated in proctography [8]. Kuon et al. [13] demonstrated that additional security measures could drastically reduce radiation exposure in interventional cardiology. Zweers et al. [17] found that in TIPS, the use of dedicated fluoroscopy exposure factors, with a relatively high tube voltage and lower tube current resulted in a significant dose reduction to patients and staff. Some of these interventions could also be performed on open MRI systems to avoid ionising radiations.

Clearly these results need to be confirmed in larger series under different conditions, including improved filtering and reduced radiation-dose protocols, but they underline the importance of radiation protection for the personnel involved in these procedures which are being performed increasingly frequently.

\section{References}

1. Martin JB, Jean B, Sugiu K, et al (1999) Vertebroplasty: clinical experience and follow-up results. Bone 25 [Suppl 2]:11S-15S

2. Grados F, Depriester C, Cayrolle G, Hardy N, Deramond H, Fardellone P (2000) Long-term observations of vertebral osteoporotic fractures treated by percutaneous vertebroplasty. Rheumatology 39:1410-1414

3. Mathis JM, Barr JD, Belkoff SM, Barr MS, Jensen ME, Deramond H (2001) Percutaneous vertebroplasty: a developing standard of care for vertebral compression fractures. AJNR 22:373381
4. Deramond H, Depriester C, Galibert P, Le Gars D (1998) Percutaneous vertebroplasty with polymethylmethacrylate. Technique, indications, and results. Radiol Clin North Am 36:533-546

5. Miller DL, Balter S, Noonan PT, Georgia JD (2002) Minimizing radiation-induced skin injury in interventional radiology procedures. Radiology 225:329-336

6. Fletcher DW, Miller DL, Balter S, Taylor MA (2002) Comparison of four techniques to estimate radiation dose to skin during angiographic and interventional radiology procedures. $\mathrm{J}$ Vasc Interv Radiol 13:391-397

7. Papadimitriou D, Perris A, Molfetas MG, et al (2001) Patient dose, image quality and radiographic techniques for common $\mathrm{X}$ ray examinations in two Greek hospitals and comparison with European guidelines. Radiat Prot Dosimetry 95:43-48
8. Hare C, Halligan S, Bartram CI, Gupta R, Walker AE, Renfrew I (2001) Dose reduction in evacuation proctography. Eur Radiol 11:432-434

9. Mooney RB, McKinstry J (2001) Paediatric dose reduction with the introduction of digital fluorography. Radiat Prot Dosimetry 94:117-120

10. Kotre CJ, Marshall NW (2001) A review of image quality and dose issues in digital fluorography and digital subtraction angiography. Radiat Prot Dosimetry 94:73-76 
11. Marshall NW, Chapple CL, Kotre CJ (2000) Diagnostic reference levels in interventional radiology. Phys Med Biol 45:3833-3846

12. Langer M, Golde G, Fiegler W, Felix R (1984) Radiation exposure of the examiner during digital subtraction angiography in the continuous-mode operation. Fortschr Geb Röntgenstr Nuklearmed 141:544-545

13. Kuon E, Schmitt M, Dahm JB (2002) Significant reduction of radiation exposure to operator and staff during cardiac interventions by analysis of radiation leakage and improved lead shielding. Am J Cardiol 89:44-49
14. Britton CA, Wholey MH (1988) Radiation exposure of personnel during digital subtraction angiography. Cardiovasc Intervent Radiol 11:108-110

15. Fransson SG, Persliden J (2000) Patient radiation exposure during coronary angiography and intervention. Acta Radiol 41:142-144

16. Fuchs M, Modler H, Schmid A, Dumont C, Sturmer KM (1999) Measuring intraoperative radiation exposure of the trauma surgeon. Measuring eye, thyroid gland and hand with highly sensitive thermoluminescent detectors. Unfallchirurg 102:371-376

17. Zweers D, Geleijns J, Aarts NJ, et al (1998) Patient and staff radiation dose in fluoroscopy-guided TIPS procedures and dose reduction, using dedicated fluoroscopy exposure settings. Br J Radiol 71:672-676
18. Waggershauser T, Herrmann K, Schatzl M, Reiser M (1995) Reducing radiation dosage with modern DSA equipment. Radiologe 35:148-151

19. Ishiguchi T, Nakamura H, Okazaki M, et al (2000) Radiation exposure to patient and radiologist during transcatheter arterial embolization for hepatocellular carcinoma. Nippon Igaku Hoshasen Gakkai Zasshi 60:839-844 